\title{
Some effects of selenium deficiency on glutathione peroxidase (EC 1.11.1.9) activity and tissue pathology in rainbow trout (Salmo gairdneri)
}

\author{
BY J. G. BELL, B. J. S. PIRIE, J. W. ADRON AND C. B. COWEY \\ Institute of Marine Biochemistry, St Fittick's Road, Aberdeen AB1 3RA
}

(Received 22 February 1985 - Accepted 12 September 1985)

\begin{abstract}
1. Two duplicate groups of rainbow trout (Salmo gairdneri; mean weight $27 \mathrm{~g}$ ) were given diets of differing selenium content (deficient $0.025 \mathrm{mg} \mathrm{Se} / \mathrm{kg}$; supplemented $1.022 \mathrm{mg} \mathrm{Se} / \mathrm{kg}$ ) for 30 weeks.

2. There were no significant differences between treatments in weight gain but packed cell volume, liver vitamin $E$ and liver and plasma Se concentrations were all significantly lower in the Se-deficient trout.

3. Ataxia occurred in about $10 \%$ of the Se-deficient trout and histopathologies were evident in nerve cord (damage to axon sheath) and liver (loss of integrity in endoplasmic reticulum and mitochondria with appearance of increased vesiculation).

4. Glutathione peroxidase ( $E C$ 1.11.1.9) activity was significantly reduced in liver and plasma of Se-deficient fish but there was no indication, from differential assay, of any non-Se-dependent glutathione peroxidase activity. Glutathione transferase ( $E C$ 2.5.1.18) activity was significantly increased in Se-deficient trout.
\end{abstract}

Although selenium has long been recognized as an essential dietary nutrient in a variety of domestic animals (Schwarz \& Folz, 1957; Oh et al. 1976; Siddons \& Mills, 1981; Xu \& Diplock, 1983), few pathological or metabolic changes have been observed in rainbow trout (Salmo gairdneri) depleted of Se. Diets containing 0.06-0.07 mg Se $/ \mathrm{kg}$ (Hilton et al. 1980; Bell et al. 1985) and fed continuously over a prolonged period (up to 40 weeks) did not adversely affect growth rate and although hepatic and plasma glutathione (GSH) peroxidase (EC 1.11.1.9) activities were greatly reduced, tissue indices of antioxidant capacity, such as erythrocyte fragility, were not significantly affected. In particular, hepatic glutathione transferase ( $E C$ 2.5.1.18) activity was not altered by this Se depletion. This enzyme is responsible for the Se-independent GSH peroxidase activity present in rats (Pierce \& Tappel, 1978), an activity that has been shown to increase during Se deficiency (Lawrence et al. 1978).

While GSH transferase purified from rainbow trout liver did not show GSH peroxidase activity, it did inhibit lipid peroxidation in trout liver microsomes in vitro (Bell et al. 1984).

The lack of effect of Se depletion in rainbow trout in these experiments (Hilton et al. 1980; Bell et al. 1985) may have been because dietary concentrations of $0.06-0.07 \mathrm{mg} \mathrm{Se} / \mathrm{kg}$ do not induce a sufficiently-marked deficiency. In the experiments reported here, dietary Se was reduced to $0.02 \mathrm{mg} \mathrm{Se} / \mathrm{kg}$ by replacing casein in the diet with a mixture of free amino acids of similar composition in an attempt to induce a more marked Se deficiency.

\section{MATERIALS AND METHODS \\ Animals and diets}

Rainbow trout were obtained from Selcoth Fisheries, Moffat; they had a mean weight of approximately $27 \mathrm{~g}$ and they were randomly distributed (thirty fish/tank) between four fibre-glass tanks of diameter $1 \mathrm{~m}$, depth $0.6 \mathrm{~m}$, and containing 500 litres water. The water, from Aberdeen city domestic supply, passed through an activated-charcoal filter to the tanks with a total flow to each tank of 10 litres/min. The ambient temperature in the aquarium room averaged $15^{\circ}$ and the photoperiod was $12 \mathrm{~h}$ light $-12 \mathrm{~h}$ dark. 
Table 1. Composition of the basal diet $(\mathrm{g} / \mathrm{kg}$ dry diet $)$

\begin{tabular}{lr}
\hline Torula yeast & 350 \\
Cod-liver oil* & 100 \\
Vitamin mix $\dagger$ & 28 \\
Mineral mix $\$$ & 40 \\
Starch & $157 \cdot 1$ \\
Antioxidant mix $\S$ & $0 \cdot 4$ \\
Amino acid mixture & $324 \cdot 5$ \\
\hline
\end{tabular}

* Super Solvitax; British Cod Liver Oils Ltd, Hull.

† Supplied (/kg diet): thiamin hydrochloride $50 \mathrm{mg}$, riboflavin $200 \mathrm{mg}$, pyridoxine hydrochloride $50 \mathrm{mg}$, nicotinic acid $750 \mathrm{mg}$, calcium pantothenate $500 \mathrm{mg}$, myo-inositol $2 \mathrm{~g}$, biotin $5 \mathrm{mg}$, folic acid $15 \mathrm{mg}$, choline bitartrate $9 \mathrm{~g}$, ascorbic acid $1 \mathrm{~g}$, menaphthone $40 \mathrm{mg}$, cyanocobalamin $0.09 \mathrm{mg}$, DL- $\alpha$-tocopheryl acetate $400 \mathrm{mg}$.

† Supplied (g/kg diet): $\mathrm{Ca}\left(\mathrm{H}_{2} \mathrm{PO}_{4}\right)_{2} \cdot \mathrm{H}_{2} \mathrm{O} 27 \cdot 6, \mathrm{CaCO}_{3} 2 \cdot 1, \mathrm{MgCO}_{3} 3 \cdot 6, \mathrm{FeSO}_{4} \cdot 7 \mathrm{H}_{2} \mathrm{O} 1 \cdot 2, \mathrm{KCl} 2 \cdot 0, \mathrm{NaCl} 3 \cdot 2$, $\mathrm{Al}_{2}\left(\mathrm{SO}_{4}\right)_{3} .16 \mathrm{H}_{2} \mathrm{O} 0 \cdot 008, \mathrm{ZnSO}_{4} .7 \mathrm{H}_{2} \mathrm{O} 0 \cdot 16, \mathrm{CuSO}_{4} 0 \cdot 04, \mathrm{MnSO}_{4} .4 \mathrm{H}_{2} \mathrm{O} 0 \cdot 14, \mathrm{KI} 0 \cdot 008, \mathrm{CoSO}_{4} 0.04$.

$\$$ Contained $(\mathrm{g} / \mathrm{l}): 200$ butylated hydroxyanisole, 60 propyl gallate and 40 citric acid dissolved in propylene glycol.

|| Supplied (g/kg diet): lysine 32, histidine $12 \cdot 2$, arginine $21 \cdot 6$, threonine $14 \cdot 6$, valine $15 \cdot 8$, methionine 6 , isoleucine $13 \cdot 6$, leucine $28 \cdot 3$, phenylalanine $13 \cdot 2$, tryptophan $4 \cdot 3$, aspartic acid $32 \cdot 1$, serine $15 \cdot 9$, glutamic acid 50 , proline $12 \cdot 2$, glycine $14 \cdot 9$, alanine $21 \cdot 7$, tyrosine $11 \cdot 3$, cystine $4 \cdot 8$.

The fish were weaned from a commercial diet onto the basal diet (Table 1) and about 1 week later initial weight measurements were made on individual fish which had been anaesthetized with MS222 (ethyl $m$-aminobenzoate methane sulphonate; Sigma Chemical Co. Ltd, Poole, Dorset; $0.2 \mathrm{~g} / \mathrm{l}$ ). Fish were fed at a rate of $20 \mathrm{~g} / \mathrm{kg}$ biomass per $\mathrm{d}$ (four or five times per d), $6 \mathrm{~d}$ each week. Any food uneaten from the daily ration was weighed and recorded. Fish were weighed at 28 -d intervals and the ration adjusted accordingly. The experiment lasted 30 weeks.

The basal diet (Table 1) was formulated to meet the nutritional requirements of trout other than for Se (diet 1). The complete diet had Se added as sodium selenite to $1 \mathrm{mg} / \mathrm{kg}$ (diet 2). The dry dietary components were mixed in a Hobart commercial mixer (Model A200; Hobart Manufacturing Co. Ltd, London), then formed into a paste by adding $300 \mathrm{ml}$ water $/ \mathrm{kg}$ powder. The paste was extruded through the mincer using an appropriate die to provide pellets of suitable size for the fish. After freeze-drying, the material was broken into pellets of approximately $5 \mathrm{~mm}$ length. Each of the two diets was fed to duplicate groups (tanks) of fish.

\section{Analytical methods}

Each analytical measurement was carried out on six individuals from each treatment, i.e. three individuals were selected at random from each tank. Blood samples were taken from the caudal vein into tubes containing sodium EDTA as anticoagulant.

$\mathrm{Se}$ in water, diets and tissues was measured as described by Hasunuma et al. (1982). Vitamin $E$ in diets was extracted by the method of McMurray et al. (1980) and from tissues as described previously (Cowey et al. 1981). In both cases measurement of vitamin $\mathrm{E}$ was performed by high-performance liquid chromatography (Hung et al. 1980) with fluorometric detection (model LS4 fluorescence spectrometer; Perkin-Elmer, Beaconsfield, Bucks.). Liver microsomes were prepared as described by Bell et al. (1984) and $\mathrm{Fe}^{2+} \mathrm{NADPH}$-stimulated oxidation of microsomal lipids was as described by Bell et al. (1984). All enzyme assays were performed at $20^{\circ}$. Livers were homogenized in 9 vol. 20 -mM-Tris-hydrochloric acid $(\mathrm{pH} 7 \cdot 4), 1 \mathrm{~mm}$-dithiothreitol and Triton X-100 (10 mg/g) and the resulting homogenate used in the assay of GSH peroxidase and GSH transferase. For GSH peroxidase the rate 
Table 2. Selenium and vitamin $E$ contents of the experimental diets together with values for weight gain of rainbow trout (Salmo gairdneri) given the diets for 30 weeks

(Mean values with their standard errors for thirty fish per tank)

\begin{tabular}{|c|c|c|c|c|c|c|c|c|}
\hline \multirow[t]{2}{*}{$\operatorname{Diet}^{*} \ldots$} & \multicolumn{4}{|c|}{1} & \multicolumn{4}{|c|}{2} \\
\hline & \multicolumn{2}{|c|}{ Mean } & \multicolumn{2}{|c|}{ SE } & \multicolumn{2}{|c|}{ Mean } & \multicolumn{2}{|c|}{$\mathrm{SE}$} \\
\hline $\begin{array}{l}\text { Measured } \mathrm{Se}(\mathrm{mg} / \mathrm{kg}) \\
\text { Measured vitamin E g/kg }\end{array}$ & \multicolumn{2}{|c|}{$\begin{array}{l}0.025 \\
0.63\end{array}$} & \multicolumn{2}{|c|}{$\begin{array}{l}0.004 \\
0.06\end{array}$} & \multicolumn{2}{|c|}{$\begin{array}{l}1.022 \\
0.56\end{array}$} & \multicolumn{2}{|c|}{$\begin{array}{l}0.041 \\
0.08\end{array}$} \\
\hline \multirow[t]{2}{*}{ Tank... } & \multicolumn{2}{|c|}{ A } & \multicolumn{2}{|c|}{ B } & \multicolumn{2}{|c|}{$\mathrm{C}$} & \multicolumn{2}{|c|}{$\mathrm{D}$} \\
\hline & Mean & $\mathrm{SE}$ & Mean & $\mathbf{S E}$ & Mean & SE & Mean & $\mathrm{SE}$ \\
\hline $\begin{array}{l}\text { Initial wt (g) } \\
\text { Final wt }(\mathrm{g})\end{array}$ & $\begin{array}{r}25 \cdot 70 \\
144 \cdot 46\end{array}$ & $\begin{array}{l}1 \cdot 24 \\
8 \cdot 47\end{array}$ & $\begin{array}{r}26 \cdot 34 \\
155 \cdot 94\end{array}$ & $\begin{array}{r}1.74 \\
12.76\end{array}$ & $\begin{array}{r}26 \cdot 57 \\
159 \cdot 37\end{array}$ & $\begin{array}{r}2 \cdot 01 \\
10 \cdot 63\end{array}$ & $\begin{array}{r}28 \cdot 12 \\
163 \cdot 87\end{array}$ & $\begin{array}{l}2 \cdot 11 \\
9 \cdot 62\end{array}$ \\
\hline Feed intake: wt gain & 1.71 & & 1.61 & & $1 \cdot 54$ & & $1 \cdot 50$ & \\
\hline
\end{tabular}

* For details, see Table 1.

of oxidation of NADPH was followed at $340 \mathrm{~nm}$ by the coupled reaction with GSH reductase $(\mathrm{NAD}(\mathrm{P}) \mathrm{H})(E C$ 1.6.4.2). The reaction mixture contained $1 \mathrm{mM}-\mathrm{GSH}, 1.5 \mathrm{~mm}-$ cumene hydroperoxide or $0.25 \mathrm{~mm}$-hydrogen peroxide, $0.1 \mathrm{~mm}$-NADPH, 1.0 unit GSH reductase (Sigma Chemical Co. Ltd; 1 unit oxidizes $1 \mu \mathrm{mol} \mathrm{NADPH} / \mathrm{min}$ ), $1 \mathrm{~mm}$-EDTA, $2 \mathrm{~mm}$-sodium azide and $50 \mathrm{~mm}$-potassium phosphate buffer, $\mathrm{pH} 7 \cdot 4$. GSH transferase activity was assayed by following the conjugation of 1-chloro-2,4-dinitrobenzene with GSH at $340 \mathrm{~nm}$ (Habig et al. 1974). The assay contained, final concentrations, $100 \mathrm{~mm}$-potassium phosphate (pH 6.5), 2 mM-GSH and 1 mM-chloro-2,4-dinitrobenzene. Protein was measured by the method of Lowry et al. (1951). Plasma pyruvate kinase (EC 2.7.1 .40) was measured as described by Bell et al. (1985).

\section{Histology}

Small portions of liver, muscle and nerve cord were fixed overnight in glutaraldehyde (25 g/l), 0.1 M-phosphate buffer ( $\mathrm{pH} 7 \cdot 6$ ), saline ( $5 \mathrm{~g}$ sodium chloride/l, giving an osmolarity of $650 \mathrm{mosmol} / \mathrm{l})$ and washed in $0.1 \mathrm{M}$-phosphate buffer, $\mathrm{NaCl}(15 \mathrm{~g} / \mathrm{l})$. After dehydration, blocks were embedded in 'Emix' resin (Emscope Laboratories Ltd, Ashford, Kent). Sections $(0.5 \mu \mathrm{m})$ were stained with toluidine blue $(10 \mathrm{~g} / \mathrm{l})$ sodium tetraborate $(10 \mathrm{~g} / 1)$ at $70^{\circ}$ for $1 \mathrm{~min}$ before examination under a light microscope. Sections $(15 \mathrm{~nm})$ were stained with uranyl acetate and lead citrate and examined in a Jeol 100CX electron microscope operating at $60 \mathrm{kV}$.

\section{Statistical analysis}

The differences in growth due to experimental treatments were determined by analysis of variance (at the $99 \%$ probability level) of the initial and final weights of individual fish. Significance of differences between treatments for packed cell volume, liver vitamin $\mathrm{E}$, liver and plasma Se, liver and plasma GSH peroxidase, liver and plasma GSH transferase and plasma pyruvate kinase was assessed by Student's $t$ test.

\section{RESULTS}

Initial and final weights of trout given the two diets are shown in Table 2. Good growth rates were obtained on both treatments and there were no significant differences in weight 
gain in any of the tanks. Feed intake: weight gain values (Table 2) were comparatively high but this has frequently been the case when trout are given diets containing large quantities of free amino acids (Walton et al. 1982); there were no significant differences between treatments. No mortalities occurred nor were any gross pathologies evident in fish given the control (Se-supplemented) diet. About 10\% of fish fed on the Se-deficient diet developed ataxia, i.e. an abnormal swimming action in which they swam either on their sides or in a totally-inverted fashion.

No signs of pathology were discernible by light microscopy in the tissues of Se-deficient fish. Electron microscopy of liver from control trout (Plate 1(a)) gave a conventional picture, the cells being characterized by parallel rows of rough endoplasmic reticulum bordering the cell membrane and surrounding the nucleus in which the chromatin was dispersed. Mitochondria were in close association with the rough endoplasmic reticulum and scattered throughout the cytoplasm but excluded from the large glycogen pools which occupied up to $30 \%$ of the cell volume. Vesicles, some containing glycogen and fine electron-dense material, others with distinct particles - possibly low-density lipoproteins, occurred frequently. Lysosomes and residual bodies were present toward the bile canaliculus edge of the cells.

Hepatocytes from Se-deficient fish (Plate $1(b)$ ) were characterized by condensed chromatin in the nucleus and a prominent nucleolus. The endoplasmic reticulum was swollen and spaces between cisternae enlarged with apparent loss of ribosomes, giving the cells an appearance of increased vesiculation. Glycogen was plentiful but there was loss of integrity in the mitochondria with the cristae often being ill-defined. Residual bodies with heterogeneous contents of varying electron density occurred more frequently than in control fish. Electron microscopy of livers of the ataxic Se-deficient trout (Plate $1(c)$ ) showed mitochondria that were internally disintegrated and nuclei that were distorted; large vacuoles were present in the glycogen pools.

No gross structural changes were seen in electron micrographs of muscle tissue, myofibrillar structure being intact in both control and Se-deficient fish. Nerve cord from control fish (Plate $2(a)$ ) had normally myelinated axons with typical neurotubules, neurofilaments, vesicles and occasional mitochondria within the axoplasm. Considerable damage to the axon sheath occurred in Se-deficient fish (Plate $2(b)$ ) and vacuolation of the axoplasm was evident with loss of organelles.

The greater degree of Se-deficiency indicated by tissue Se levels (Table 3) probably led to a reduction in packed cell volume that had not been observed previously (Bell et al. 1985). No thiobarbituric-acid-positive material was found when microsomes from the livers of control or Se-deficient fish were incubated under oxidizing ( $\left.\mathrm{Fe}^{2+}-\mathrm{NADPH}\right)$ conditions in vitro. This was probably due to the high levels of vitamin $\mathrm{E}$ present in livers of both Se-deficient and control fish (Table 3). These levels reflected the high dietary intake. Vitamin $\mathrm{E}$ is known to inhibit malondialdehyde formation in the in vitro microsomal system (Bell et al. 1984; Cadenas et al. 1984).

Se concentrations in liver and plasma were very greatly reduced by the Se-deficient diet and values were markedly lower than in a corresponding treatment of earlier experiments (Bell et al. 1985). Even so the levels attained are still more than double those reported by Oh et al. (1976) for Se-deficient lambs.

The activities of liver and plasma GSH peroxidase are shown in Table 4. While the decrease in activity in the Se-deficient state is in line with all previous results, the differential assay with hydrogen peroxide and organic peroxides again does not reveal any convincing evidence for the presence of a non-Se-dependent GSH peroxidase activity (cf. Bell et al. 1984,1985 ). For example the ratio, activity measured with cumene hydroperoxide: activity measured with $\mathrm{H}_{2} \mathrm{O}_{2}$ can be shown to be 210 in the livers of Se-deficient rats and 2.5 in 
Table 3. Packed cell volume, liver vitamin $E$ concentration $(\mu \mathrm{g} / \mathrm{g}$ wet tissue) and liver and plasma selenium concentrations $(\mu \mathrm{g} / \mathrm{g}$ wet tissue or $\mu \mathrm{g} / \mathrm{ml}$ ) in rainbow trout (Salmo gairdneri) given the experimental diets*

(Mean values with their standard errors for six fish per treatment)

\begin{tabular}{|c|c|c|c|c|c|}
\hline & \multicolumn{2}{|c|}{ Diet 1} & \multicolumn{2}{|c|}{ Diet 2} & \multirow{2}{*}{$\begin{array}{c}\text { Statistical } \\
\text { significance } \\
\text { of difference } \\
P<\end{array}$} \\
\hline & Mean & $\mathrm{SE}$ & Mean & SE & \\
\hline Packed cell volume & 0.298 & 0.025 & 0.418 & 0.070 & 0.001 \\
\hline Liver vitamin $\mathrm{E}$ & $227 \cdot 4$ & $30 \cdot 89$ & $342 \cdot 4$ & $41 \cdot 64$ & 0.01 \\
\hline Liver $\mathrm{Se}$ & $0 \cdot 122$ & 0.019 & $1 \cdot 321$ & $0 \cdot 258$ & 0.001 \\
\hline Plasma Se & 0.031 & 0.006 & $0 \cdot 219$ & 0.038 & 0.001 \\
\hline
\end{tabular}

* For details of diets, see Table 1.

Table 4. Activities (nmol NADPH oxidized/min per $m g$ protein or per $m l$ plasma) of glutathione $(G S H)$ peroxidase (EC 1.11.1.9) in livers and plasma of rainbow trout (Salmo gairdneri) given the experimental diets*

(Mean values with their standard errors for six fish per treatment)

\begin{tabular}{|c|c|c|c|c|c|}
\hline & \multicolumn{2}{|c|}{ Diet 1} & \multicolumn{2}{|c|}{ Diet 2} & \multirow{2}{*}{$\begin{array}{c}\text { Statistical } \\
\text { significance } \\
\text { of difference: } \\
P<\end{array}$} \\
\hline & Mean & SE & Mean & SE & \\
\hline Plasma GSH peroxidase $\dagger$ & $57 \cdot 35$ & $4 \cdot 74$ & $402 \cdot 15$ & $30 \cdot 79$ & 0.001 \\
\hline Liver GSH peroxidaseł & $2 \cdot 50$ & 0.68 & $14 \cdot 38$ & $1 \cdot 83$ & 0.001 \\
\hline Liver GSH peroxidase & $5 \cdot 05$ & $0 \cdot 85$ & $18 \cdot 60$ & 1.72 & 0.001 \\
\hline
\end{tabular}

the livers of Se-supplemented rats (Lawrence et al. 1978). The ratio in trout given Se-deficient diet 1 was 2.20 (SE 0.48) compared with 1.31 (SE 0.06) for trout given the control diet. These values, although dissimilar, are not significantly different and are not good evidence either for or against the presence of a non-Se-dependent GSH peroxidase.

Again GSH peroxidase activity in the Se-deficient fish was reduced by $73 \%$ compared with control fish when cumene hydroperoxide was used as substrate. The corresponding value with $\mathrm{H}_{2} \mathrm{O}_{2}$ as substrate was $83 \%$. These values do not support the view that a Se-independent GSH peroxidase is present in trout.

There were significant increases in the activities of GSH transferase in both liver and plasma of Se-deficient fish (Table 5). This result contrasts with our earlier findings on trout depleted of Se (Bell et al. 1985). The increased activity is similar to that reported in rats given a Se-deficient diet (Lawrence et al. 1978).

The mean activity of plasma pyruvate kinase was enhanced in Se-deficient trout (Table 5). Even higher values occurred in those fish showing the abnormal swimming action ( $115 \cdot 23$ (SE 43.4) nmol NADH oxidized/min per mg protein). This may be due to leakage from tissues suffering structural damage into plasma. 
Table 5. Activities of glutathione (GSH) transferase (EC 2.5.1.18) from plasma and liver and pyruvate kinase (EC 2.7.1.40) from plasma of rainbow trout (Salmo gairdneri) given the experimental diets*

(Mean values with their standard errors for six fish per treatment)

\begin{tabular}{|c|c|c|c|c|c|}
\hline & \multicolumn{2}{|c|}{ Diet 1} & \multicolumn{2}{|c|}{ Diet 2} & \multirow{2}{*}{$\begin{array}{c}\text { Statistical } \\
\text { significance } \\
\text { of difference } \\
P<\end{array}$} \\
\hline & Mean & $\mathrm{SE}$ & Mean & SE & \\
\hline Liver GSH transferase $\dagger$ & 0.713 & 0.072 & 0.311 & 0.034 & 0.001 \\
\hline Plasma GSH transferase & $2 \cdot 79$ & $0 \cdot 22$ & 0.66 & $0 \cdot 14$ & 0.001 \\
\hline Plasma pyruvate kinase $\$$ & $1 \cdot 38$ & $0 \cdot 23$ & 0.76 & 0.08 & $0 \cdot 05$ \\
\hline
\end{tabular}

* For details of diets, see Table 1.

$\mp \mu \mathrm{mol}$ thioester bond formed/min per $\mathrm{mg}$ protein.

nmol thioester bond formed/min per $\mathrm{mg}$ protein.

$\S \mathrm{nmol} \mathrm{NADH}$ oxidized/min per mg protein; values were log transformed before analysis.

\section{DISCUSSION}

In previous studies (Hilton et al. 1980; Bell et al. 1985) no frank Se-deficiency symptoms have been found in trout when diets contained an adequate amount of vitamin $E$. In the present study dietary Se levels were lower than those attained previously in experiments with fish $(0.025 \mu \mathrm{g} \mathrm{Se} / \mathrm{g}$ diet $)$ and it is evident that, when Se deficiency is sufficiently severe, tissue pathologies do arise even when diets contain high concentrations of vitamin $\mathrm{E}$.

It is of interest that while the concentration of Se in the livers of trout in the present experiment was very much lower than that in an earlier experiment (Bell et al. 1985), the activity of GSH peroxidase was very similar in the two experiments. This suggests that $\mathrm{Se}$ present in GSH peroxidase is retained much more tenaciously in Se deficiency than is $\mathrm{Se}$ present in other proteins or in other states.

Recently Gatlin \& Wilson (1984) demonstrated that the growth of channel catfish (Ictalurus punctatus) is affected by dietary Se level. A basal diet containing $0.06 \mathrm{mg} \mathrm{Se} / \mathrm{kg}$ dry diet caused growth depression and a requirement level of $0.25 \mathrm{mg} \mathrm{Se} / \mathrm{kg}$ dry diet was inferred from growth data and liver and plasma 'Se GSH peroxidase' activity levels. This suggests that channel catfish are more demanding in their Se requirement than rainbow trout.

Gatlin \& Wilson (1984) provided information on 'Se GSH peroxidase' and 'non-Se GSH peroxidase' in livers and plasma of channel catfish given different dietary concentrations of Se. The basis for these findings is by no means clear, in particular, whether the "non-Se GSH peroxidase' is a measurement with cumene hydroperoxide or a differential assay with $\mathrm{H}_{2} \mathrm{O}_{2}$ and cumene hydroperoxide as substrates. If 'non-Se GSH peroxidase' does in fact represent such an activity it is difficult to see, for example, why values should be much lower at low Se intakes than at high intakes; if on the other hand 'non-Se GSH peroxidase' is actually total GSH peroxidase activity it is difficult to see why values obtained at high-Se dietary intakes are the same as values for 'Se GSH peroxidase' activity.

It remains the case that there is as yet no unequivocal evidence of a Se-independent GSH peroxidase activity in fish. 
British Journal of Nutrition, Vol. 55 No. 2

Plate 1
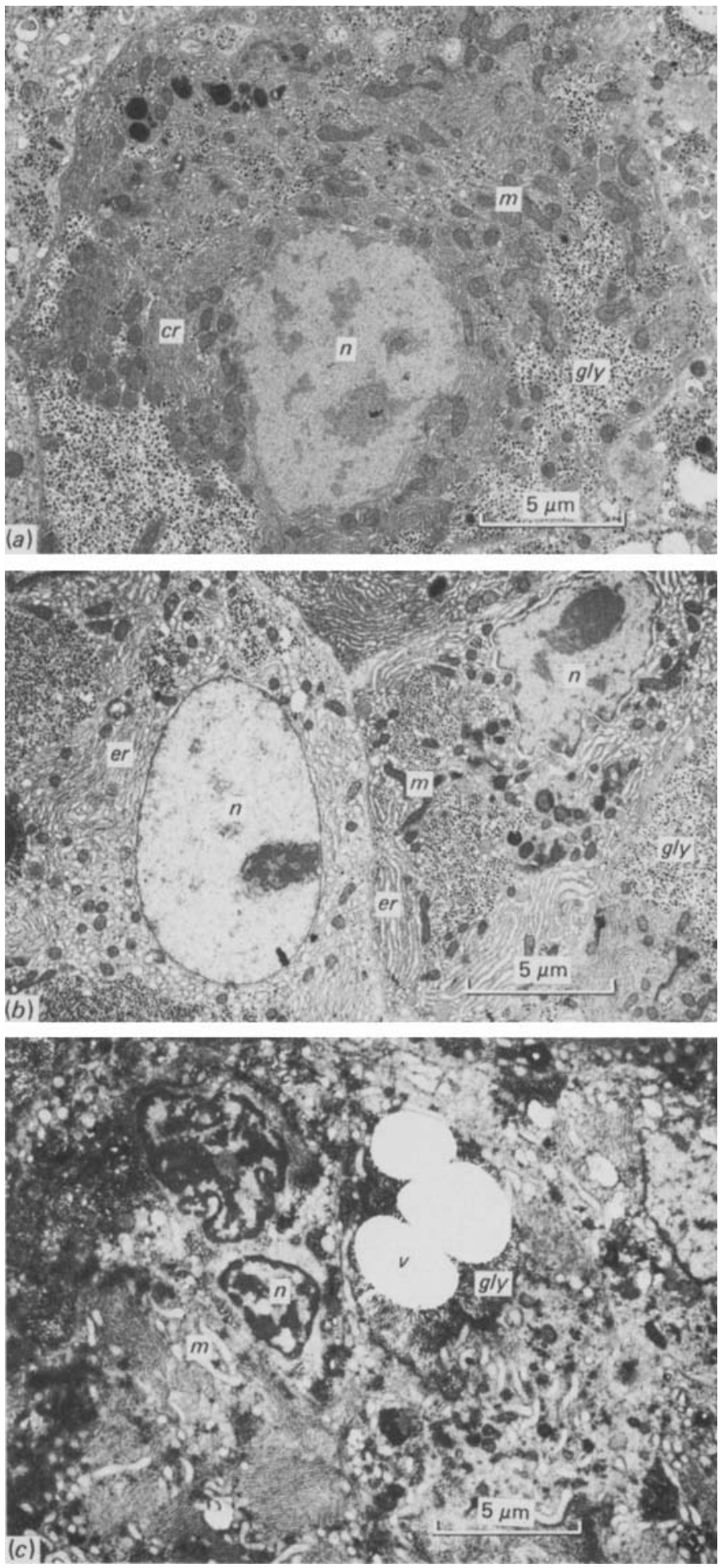
British Journal of Nutrition, Vol. 55 No. 2

Plate 2
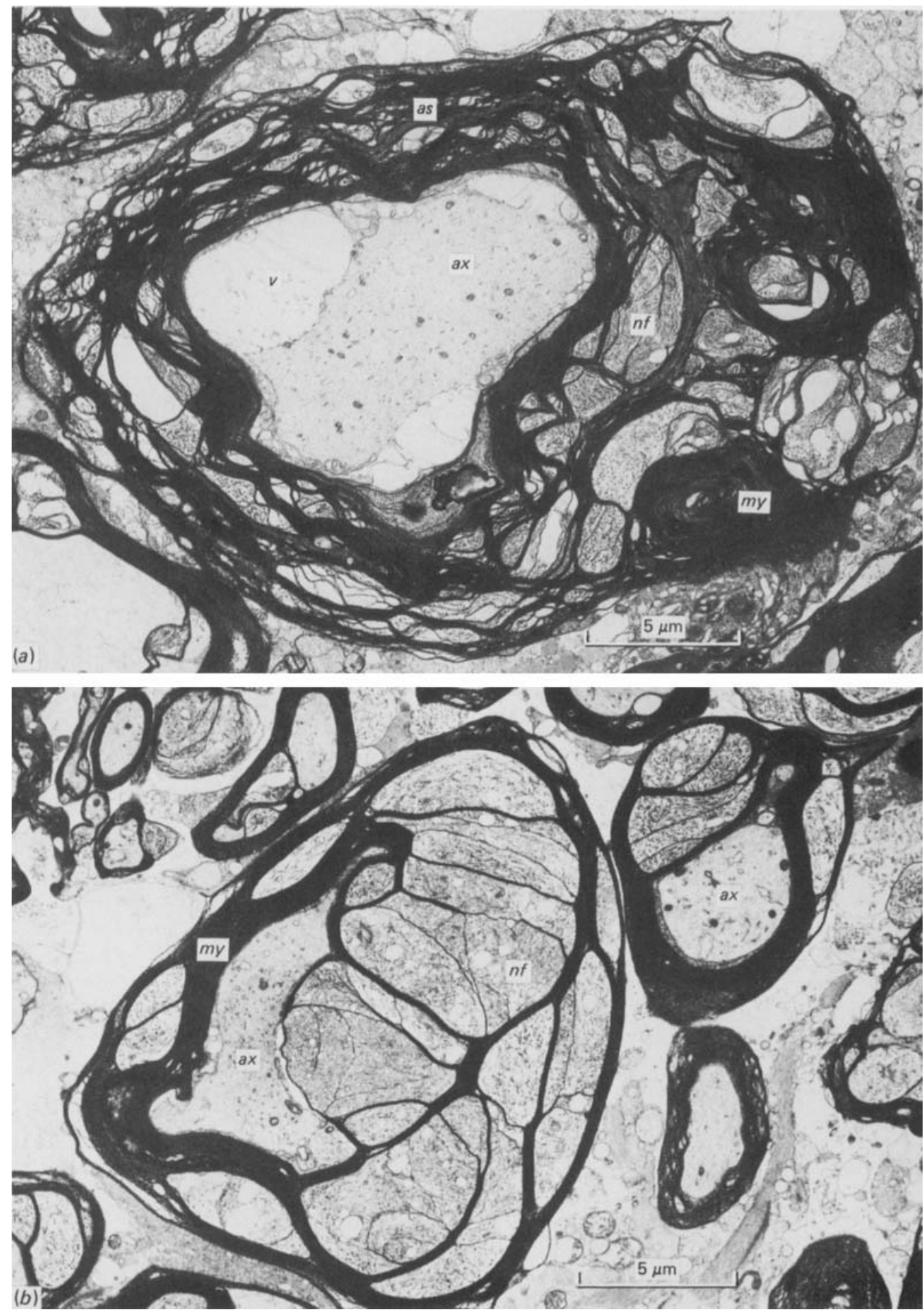


\section{REFERENCES}

Bell, J, G., Cowey, C. B., Adron, J. W. \& Shanks, A. M. (1985). British Journal of Nutrition 53, $149-157$.

Bell, J. G., Cowey, C. B. \& Youngson, A. (1984). Biochimica et Biophysica Acta 795, 91-99.

Cadenas, E., Ginsberg, M., Rabe, U. \& Sies, H. (1984). Biochemical Journal 223, 755-759.

Cowey, C. B., Adron, J. W., Walton, M. J., Murray, J., Youngson, A. \& Knox, D. (1981). Journal of Nutrition 111, 1556-1567.

Gatlin, D. M. \& Wilson, R. P. (1984). Journal of Nutrition 114, 627-633.

Habig, W. H., Pabst, M. J. \& Jackoby, W. B. (1974). Journal of Biological Chemistry 249, 7130-7139.

Hasunuma, R., Ogawa, T. \& Kawanishi, Y. (1982). Analytical Biochemistry 126, 242-245.

Hilton, J. W., Hodson, P. V. \& Slinger, S. J. (1980). Journal of Nutrition 110, 2527-2535.

Hung, S. S. O., Cho, C. Y. \& Slinger, S. J. (1980). Journal of the Association of Official Analytical Chemists 63, 889-893.

Lawrence, R. A., Parkhill, L. K. \& Burk, R. F. (1978). Journal of Nutrition, 108, 981-987.

Lowry, O. H., Roseburgh, N. J., Farr, A. L. \& Randall, R. J. (1951). Journal of Biological Chemistry 193, $265-275$.

McMurray, C. H., Blanchflower, W. J. \& Rice, D. A. (1980). Journal of the Association of Official Analytical Chemists 63, 1258-1261.

Oh, S.-H., Sunde, R. A., Pope, A. L. \& Hoekstra, W. G. (1976). Journal of Animal Science 42, 977-983.

Pierce, S. \& Tappel, A. L. (1978). Biochimica et Biophysica Acta 611, 87-98.

Schwarz, K. \& Folz, C. M. (1957). Journal of the American Chemical Society 79, 3293-3298.

Siddons, R. C. \& Mills, C. F. (1981). British Journal of Nutrition 46, 345-355.

Walton, M. J., Cowey, C. B. \& Adron, J. W. (1982). Journal of Nutrition 112, 1525-1535.

Xu, G.-L. \& Diplock, A. T. (1983). British Journal of Nutrition 50, 437-444.

\section{EXPLANATION OF PLATES}

Plate 1. Electron micrographs of livers from rainbow trout (Salmo gairdneri) fed on (a) selenium-supplemented diet (diet 2), (b) Se-deficient diet (diet 1), (c) Se-deficient diet and showing ataxia. er, Endoplasmic reticulum; gly, glycogen; m, mitochondria; $\mathrm{n}$, nucleus; v, vacuole. For diet compositions, see Table 1.

Plate 2. Electron micrographs of nerve cords from rainbow trout (Salmo gairdneri) fed on (a) seleniumsupplemented diet (diet 2), (b) Se-deficient diet (diet 1). as, Axon sheath; ax, axoplasm; my, myelin; nf, neurofilaments; v, vacuole. For diet compositions, see Table 1. 